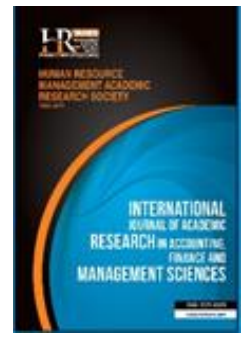

International Journal of Academic Research in Accounting, Finance and Management Sciences

Vol. 8, No.3, July 2018, pp. 277-286

E-ISSN: 2225-8329, P-ISSN: 2308-0337

(c) 2018 HRMARS

www.hrmars.com

To cite this article: Imo, O.T., Des-Wosu, C. (2018). An Assessment on the Effect of Budgetary Control on Return on Assets and Net Profit of Government-Owned Companies in Rivers State, International Journal of Academic Research in Accounting, Finance and Management Sciences 8 (3): 277-286.

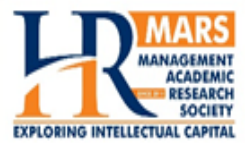

(http://dx.doi.org/10.6007/IJARAFMS/v8-i3/4836 (DOI: 10.6007/IJARAFMS/v8-i3/4836)

\title{
An Assessment on the Effect of Budgetary Control on Return on Assets and Net Profit of Government-Owned Companies in Rivers State
}

\author{
ThankGod O. IMO1, Chika DES-WOSU² \\ ${ }^{1}$ Department of Accountancy, Faculty of Management Sciences, Rivers state university Nkpolu-Orworukwo, Portharcourt \\ ${ }^{1}$ E-mail: thankgodimo17@gmail.com \\ ${ }^{2}$ Busary Department, Rivers State University Nkpolu-Oroworukwo Portharcourt, ${ }^{2} E$-mail: goldenwosu@gmail.com
}

\begin{abstract}
This study is an assessment on the effect of budgetary control on return on assets and net profit of government-owned companies in rivers state. Descriptive survey research design was used for this study. Questionnaires were administered to the organizations under investigation. Pearson product moment correlation coefficient and frequency tables were used to analyse the returned data. Statistical package for social sciences version 20 was utilized to test the effect of the independent variable on the dependent variable. The study reveals positive significant relationship between budgetary control and financial performance of government-owned companies in Rivers state on the basis of net profit and returns on assets. Based on the findings, the study concludes that budgetary control system can be used as a control mechanism to strengthen performance measurement systems. Organizations should put in place appropriate budgetary control systems which will assist in accomplishing a principle and element of the budget process. The study therefore recommends that for improved performance in these companies, GOCs should continue to adopt improved budgetary control measures in totality.

Key words Budgetary control, Return on Assets, net profit, Government-Owned Companies

Received: 10 Oct 2018 (c) The Authors 2018

Revised: 25 Oct 2018 Published by Human Resource Management Academic Research Society (www.hrmars.com

Accepted: $\quad 30$ Oct 2018 This article is published under the Creative Commons Attribution (CC BY 4.0) license. Anyone may Published Online: 16 Nov 2018 reproduce, distribute, translate and create derivative works of this article (for both commercial and noncommercial purposes), subject to full attribution to the original publication and authors. The full terms of this license may be seen at: http://creativecommons.org/licences/by/4.0/legalcode
\end{abstract}

\section{Introduction}

Many developing countries in Africa have engaged in detailed planning exercises of various types in the period after independence and this has resulted in a wide range of literature on planning. Little attention was paid to budgetary controls although this is generally recognized as the main instrument for allocating resources to specific recurrent and development activities within the public business sector. In recent years, however, budget systems have received more attention and literature on public expenditure management has become more common.

The budget is increasingly recognized as the key tool for economic management (Kiringai, 2002). It is nevertheless also recognized that a country can have a sound budget and financial system and still fail to achieve its intended targets. This suggests that the rules of the game by which the budget is formulated and implemented are equally important and that they do influence outcomes (Schick, 1999). This recognition has led to a series of budget reform systems that have a broader focus on public expenditure management. Budget reforms have been attempted in Nigeria from as far back as the early 1970s but the results have not been encouraging. In recent years, a key recommendation has been to shift the focus from the annual budget to a Medium-Term Expenditure Framework approach to budgeting. 
According to Kiringai (2002) the goals of adopting the MTEF approach was to achieve Fiscal discipline - expenditure by line agencies must adhere to hard budget ceilings in order to remain within aggregate resource constraints. Allocative efficiency to expenditure allocation should address national development priorities and Operational (technical) efficiency to public expenditure should achieve explicit outputs at minimum cost by applying performance targets of output relative to inputs.

These goals however seem far from being met as public organizations in Nigeria continue to face finance related challenges linked to budgetary controls. This has been evidenced by striking of employees as a result of unmet salary demands and poor working environment. Examples of such incidences reported in Nigeria include industrial strike, doctors' strike, and ASUU strike.

This situation presents a worrying concern as the problems seem to spiral among many other public organizations. It seems that many public institutions lack enough finances to facilitate adequate remuneration to workers and provide efficiency in service delivery. While there have been attempts to address financial performance challenges in public institutions, there is hardly any concrete study that has addressed the relationship between budgetary control and financial performance of state corporations.

According to Surajkumar (2011) a budget is based on estimates, it may or may not be true. It is not substitute of management because, the efficiency and utility of the budgetary system depends on the skill and experience of the management. It cannot be executed automatically because continuous efforts are necessary for the execution of the budget. This makes organizational managers to focus more on management issues than on budgetary control.

The need for accountability and efficiency of service delivery in public organizations across Africa and in Nigeria, put's public organizations at the fore front in establishment of control systems. Most of the public sector reform programmes that have taken place in developing countries during the 21st century were introduced as part of the Structural Adjustment Programmes (SAPs) of the World Bank in the 1980s. However, most of the more recent reforms, under the influence of the New Public Management (NPM), have been driven by a combination of economic, social, political and technological factors, which have triggered the quest for efficiency and for ways to cut the cost of delivering public services. Additional factors, particularly for Africa, include lending conditionality and the increasing emphasis on good governance.

With budgetary control systems being at the center of increasing organizational efficiency and controlling costs, then the need to examine the role of the system in organization's financial performance is of paramount importance. Therefore this study seeks to assess the effect of budgetary control on return on assets and net profit of government-owned companies in rivers state.

\subsection{Statement of the Problem}

Nigerian government is still involved in many production and service delivery activities which it cannot do well, while performing poorly on those activities that should be at the core of its mandate.

Not only that the system has accumulated pension arrears but some states and agencies of the federal government are beginning to accumulate salary arrears and payments due to contractors and suppliers, the traditional instrumentality of the rolling plan has become discredited and hardly informs the preparation of the budget, and indeed major policies. The era of comprehensive planning details had become unmanageable and resources scarcity cum political intervention in priority setting had contributed in rendering the plans impotent. This stems from the fact that annual budget had not been spared either as expenditure priorities and fund releases hardly respected the provisions of the approved budget (Aduke, 2007). All this discrepancies in the public sector of the economy occur due to mismanagement of funds, corruption, and above all, lack of a standard budgetary control system. Recently there has been a debate on the issue of the effect of budgetary control system on the financial performance of government owned companies, thus the essence of this study is to address this issue.

\subsection{Objectives of the Study}

In specific terms, the research is aimed at the following:

1. To determine the extent to which Budgetary Control relates to Net Profit of Government-Owned Companies in Rivers State. 
2. To determine the extent to which Budgetary Control relates to Return on Asset of GovernmentOwned Companies in Rivers State.

\section{Literature Review}

\subsection{Budgetary Control in the Public Sector}

According to Lewis, (2013) Public sector firms' are more worried about the availability of public goods to the people. As a result they design their budgets such that only activities that are authorized and that provide maximization of management actions are allowed. This is far from the manner and approach used in the privately owned firms where the management are only concerned about profit-making. Their budgeting is a reflection of a deliberate effort to work towards a specific predetermined acceptable results as well as ensuring that all logistics are put in place to realize those results. There is more attention from the control sector to work harder towards the achievement of set goals. The control phase therefore stresses on describing the correlation between the "budgeted revenue and expenses against the actual revenue and expense activity". When the real revenues and expenditures change from the plan patterned in the budget, then curative measures are included in the control phase, the palliative action may involve modifying the budget to reveal the actual financial operations, as well as projecting the revenue properly or reorganizing expenses. The act of giving report about expenditures made on implementing and realizing the targets of the budgets is of paramount importance in showing evidence of "accountability and stewardship to the public". As a result of this, the attention has been more on "a fixed one-year planning horizon, within-year monitoring and the reporting of financial results after the close of the financial year" The financial environment now migrates towards "medium-term three-year settlements for public services", with much inclination for quicker ending, and a lot of stress on efficiency, extent of performance and the equivalent worth of money.

\subsection{Features of Budgetary Controls in Public Organizations}

Budgeting is a set of procedures by which governments ration resources among claimants and control the amount each claimant spends (Kiringai, 2002). Within this context, the budget can be used for three purposes: as an instrument of economic policy; as a tool for economic management; and as an instrument for accountability. The budget is an allocation mechanism that attempts to maximize the contribution of public expenditure to national welfare (Surajkumar, 2005). This can be achieved by ensuring that the budget process successfully allocates scarce resources so that the marginal unit of expenditure achieves the same marginal benefit in each category of expenditure.

In determining resource allocations, the budget should reflect the development agenda of a country through which it influences the attainment of national growth and investment targets (Needles, 2011). The task of budget preparation is often seen as an accounting activity that concentrates on the annual recurrent budget while planning is seen as a medium-term activity. In this approach, the annual budget ensures control over aggregate expenditure and generates detailed financial statements on resource utilization but is not concerned with broad strategic development over the medium-term (Needles, 2011; Preetabh, 2010). The budget format and classification depends on the system adopted in each country (Nafula, 2004). The IMF Manual of Government Financial Statistics describes both the economic and functional categories of expenditure: Economic classification; distinguishes between two broad categories: recurrent expenditure (including wages and salaries, other goods and services, interest payments, subsidies and transfers), and capital expenditure and net lending. This classification reflects the inherent difference between creation of capital assets and ongoing activities especially as projects give rise to additional recurrent expenditure (both to service and maintain the asset) once they are completed.

\subsection{Benefits of Budgetary Controls}

According to Scarlett, (2008), budgetary controls refer to the principles, procedures and practices of achieving given objectives through budgets. The budgetary control system helps in fixing the goals for the organization as a whole and concerted efforts made for its achievements. It enables economies in the enterprise. Preetabh (2010) highlighted the benefits of budgetary control as profit maximization; a 
budgetary control aims at maximization of profits or an organization through, proper planning and coordination of different functions, proper control over various capital and revenue expenditures and putting resources into best use. Coordination; achieved through working of different departments and sectors. Waren,(2011) noted that within an organization, different departments have a bearing on one another, this therefore makes coordination of various executive and subordinates necessary in achieving of budgetary targets.

Other budgetary benefits as indicated by Preetabh (2010) include: Specific time aims; the plans, policies and goals are decided by the top management. All efforts are put together to reach the common goal of the organization. Every department is given a target to be achieved. The efforts are directed towards achieving come specific aims. If there is no definite aim then the efforts will be wasted in pursuing different aims. As a tool for measuring performance, budgetary controls provide comparisons between the budget targets and actual targets and deviation determined; performance of each department is reported to the top management which enables introduction of management by exception.

Margah (2005) assert that budgetary controls are important tools for a county's economy this is because it allows planning for expenditure thus facilitating systematic spending. Finances are put into optimum use, extending the benefits to industry and national economy. This reduces wastage of national resources. A budgetary control could help in determination of organizational weaknesses.

According to Merika, (2008), the deviations in budgeted and actual performance will enable the determination of weak spots. This enables an organization to concentrate on those aspects where performance is less than stipulated. The management moreover takes a corrective action measures whenever there is a discrepancy in performance. By fixing targets for the employees, they are made conscious of their responsibility. Everybody knows what he is expected to do and he continues with his work uninterrupted.

\subsection{Human Factors in Budgetary Controls}

Human factors within budgetary controls may revolve around the degree to which organizations top management accepts the budget program as a vital part of company's activities. It can also be viewed in the context within which organizational management uses budgeted data. According to Perrin (2012), if a budgetary control program is to be successful, it must have complete acceptance and support of the persons who occupy key management positions. If lower or middle level management personnel sense that top management is lukewarm about budgetary controls, or if they sense that the top management simply tolerate budget as a necessary evil, then their own attitude will reflect similar lack of enthusiasm. Perrin further notes that budget is hard work and if top management is not enthusiastic and committed to budget program, then it is unlikely that anyone in the organization was either.

\subsection{Budgetary Control Process and Financial Performance of State Corporations}

According to Ashok (2009) financial performance is a subjective measure of how well a firm can use assets from its primary mode of business and generate revenues. The term (financial performance) measure's firm's general financial health over a given period of time and can be used to compare similar firms. Different methods used to measure financial performance as indicated by Needles, (2011) include; Profitability - return on investment (ROI), earnings before interest and tax (EBIT), gross profit margins. Growth - market share growth, Sales Growth. Efficiency - return on sales (ROS), return on equity (ROE). Among the indicators of an effective budget is the process undertaken before realizing the overall budgetary control system to be used in an organization. Ghosh (2005) outlines four steps that are undertaken during development of a budgetary control system. This include; Setting up plans and budgets for each functional area, like production, sales, purchase, personnel etc. as indicated in the organizational chart, measuring and recording actual performance and measuring the deviations or variance, comparing the actual performance with planned performance and measuring deviations and identifying the person/function responsible, taking corrective action and ensuring that deviation do not arise in future. According to Ghosh (2005) the comparison of actual performance with plans may indicate the need to change policies. It is however unclear the extent to which organizations undertake policy changes prompted as a corrective as indicated by a budgetary control process. 


\subsection{Challenges Affecting Budgetary Control in State Corporations}

A study on challenges facing budgetary control systems in developed countries by OECD, (2007) showed that budgets fail due to reasons such as budgets used as pressure tool, central decision making process, lack of job security and managers' lack of training. According to McMillan (2001) most often, capital budgeting and expense budgeting are distinct processes. For, instance, organizations that do practice capital budgeting make assumptions about future cash flows that are dependent on certain advertising and sales promotion outlays. However, these outlays are typically covered by the expense budget. Boquist (2008) noted that even in organizations in which the determination of the expense request is tied at the outset of capital request, the people approving the two requests do not necessarily try to ensure consistency between the two budgets, thus posing a challenge to budgetary control.

\subsection{Empirical Review}

Cropper and Drury (1996) discussed the areas of profitability analysis, budgetary controls, performance reporting and investment appraisal techniques adopted in higher education institutions. They suggested that with a rapidly changing higher education sector, and increasing pressure to extract maximum benefit from scarce resources, management accountants have to develop new approaches in the provision of financial information. This requires the financial managers of the higher learning institutions to try to develop sound systems with proper and systematic rules and procedures to allocate and distribute the scarce resources in order to achieve higher productivity.

Chai (2011) carried out a related study basically to investigate the "influence of capital budgeting techniques on the financial performance of courier companies in Kenya". The findings of the study revealed that there is a significant correlation between the capital budgeting techniques and the financial performance of courier companies. Another related study was conducted by Adongo (2012) to determine the essential features of budgetary controls in state corporations. From the findings of the study, it was revealed that a positive correlation existed between budgetary control and the financial performance of state corporations. The findings of the study also showed that "existing budgetary features reflect ability to predict financial milestones of organizations". Furthermore, several factors within budgetary controls were related to "managerial commitment, employees' motivation, employee training and competence as well as the attitude between managers and other employees towards the budget process".

\section{Research Methodology of research}

\subsection{Research Design}

This study takes the form of a descriptive survey as research design. Specifically, this study involved a correlation, non-contrived and cross-sectional survey of a particular set of selected individuals (GOC officials).

\subsection{Population, Sample Size and Questionnaire Administration}

The study population chosen for the study comprises of all eighteen Government-Owned Companies in Rivers State. Specifically, there are only four Companies for this study which include: Nigeria Engineering Works Ltd, the Presidential Hotel, Olympia Hotel, and Rison palm Ltd. In the light of this, the findings of this study will be applied generally to all the other related companies in the State. Highly knowledgeable individuals in the financial department were purposively selected as respondents in the course of the research. These individuals consist of accountants, chief internal auditors, chief accountants, internal auditors and finance managers.

\subsection{Method of data collection}

The researcher will make use of the most appropriate and suitable instrument for data collection. Two sets of data (primary and secondary) data were used. The primary data are the field data; that is, data from the respondents using questionnaire. On the other hand, secondary data are reviews of relevant literature made by the researcher. This entails reviews of already documented facts. 


\subsection{Primary Data}

In this study, primary data will be gathered with structured questionnaires. In the structured questionnaires, the respondents themselves will record their responses in spaces that will be provided in the questionnaire according to instructions.

\subsection{Secondary Data}

Information from this source was obtained through the use of textbooks and accounting journals. The information which emanated from the ideas already documented by other authors provided a rich theoretical background for the study.

\subsection{Measurement of Variables}

The independent variable or the predictor variables were evaluated on a 5-point scale in the response range and pattern of strongly agree to strongly disagree. The criterion variable was evaluated by using the objective method where the respondents were asked to indicate on a 5-point scale.
$5.0-4.5$ strongly agree
$3.5-4.4$
Agree
2.5- 3.4
Neutral
$1.5-2.4$
Disagree
$0.5-1.4$
strongly disagree

\subsection{Test of Validity}

The variables of the study in the instrument were evaluated for construct validity to ensure that they measure the expected theoretical construct or trait that it is designed to measure. Thus, where there is a correlation between a property being evaluated and the specified variables, then one can conclude that construct validity is confirmed (Black and Champion, 1976; Kiabel, 2012).

\subsection{Test of Reliability}

To "ensure reliability the survey instrument was assessed by means of Cronbach alpha coefficients, using the Statistical Package for Social Sciences (SPSS) version 20."

Cronbach's alpha was used for the coefficient.

$\alpha=\frac{N \cdot \bar{c}}{\bar{v}+(N-1) \cdot \bar{c}}$

Where:

$\mathrm{N}=$ the number of items,

$c$-bar = the average inter-item covariance among the items and;

$\mathrm{v}$-bar $=$ the average variance.

Additionally, if the average inter-item correlation is low, alpha will be low. As the average inter-item correlation increased, Cronbach's alpha increased as well (holding the number of items constant).

Table 1. Scale Reliability Perspectives

\begin{tabular}{|c|l|c|c|}
\hline S/No & \multicolumn{1}{|c|}{ Scale particulars } & Correlation & Alpha \\
\hline A & BUDGETARY CONTROL & & \\
\hline & Coefficient Alpha = 0.838 & 0.4115 & 0.9129 \\
\hline 1 & Budget control reports are used as a basis for evaluating managerial performance & 0.7379 & 0.7641 \\
\hline 2 & All transactions are recorded at obligation and payment stage. & 0.8339 & 0.7281 \\
\hline 3 & $\begin{array}{l}\text { Feedback on the extent of achievement of expected level of performance during } \\
\text { specified period are provided. }\end{array}$ & 0.7590 & 0.7536 \\
\hline 4 & Effectiveness of budgeting process at the organization are determined. & & \\
\hline B & FINANCIAL PERFORMANCE & & \\
\hline & Coefficient Alpha = 0.807 & 0.8882 & 0.8051 \\
\hline 1 & Budgetary control relates to Net Profit of your organization & 0.7436 & 0.8951 \\
\hline 2 & Budgetary control relates Return on Asset of your organization &
\end{tabular}




\subsection{Methods of Data Analysis}

The researcher employed the use of SPSS to analyze the given data. Other statistical tools used to present the results of the analysis include: the frequency tables, percentages, Pearson's product moment correlation coefficient, ( $r$ ). All the result were basically obtained from SPSS output. Descriptive analysis was adopted in the evaluation of the extent of budgetary practices in the GOCs, while the interferential analysis (Pearson's r) was used for the evaluation of the hypotheses.

\section{Data Presentation and Analysis}

\subsection{Data Presentation}

In the study, forty questionnaires were prepared and distributed to forty staff of selected government-owned companies in Rivers State out of which thirty-five copies were retrieved.

Table 2. Questionnaire administration \& retrieval

\begin{tabular}{|c|c|c|c|}
\hline GOCs & Number issued & Number returned & Percentage \\
\hline Hotel Presidential & 10 & 9 & 90 \\
\hline Nigeria Engineering Works & 10 & 9 & 90 \\
\hline Olympia Hotel & 10 & 8 & 80 \\
\hline Rison palm Ltd & 10 & 9 & 90 \\
\hline Total & 40 & 35 & 87.5 \\
\hline
\end{tabular}

Source: Research Survey, 2016

Table 2 show that 40 copies of the questionnaire were distributed out of which thirty-five, representing $87.5 \%$ of the total copies, were retrieved.

Table 3. Demographic Analysis

\begin{tabular}{|c|c|c|c|c|c|c|c|c|}
\hline Scale & \multicolumn{2}{|c|}{$\begin{array}{c}\text { Budget control reports } \\
\text { are used as a basis for } \\
\text { evaluating managerial } \\
\text { performance }\end{array}$} & \multicolumn{2}{|c|}{$\begin{array}{c}\text { It ensures all } \\
\text { transactions are } \\
\text { recorded at obligation } \\
\text { and payment stage. }\end{array}$} & $\begin{array}{c}\text { It provides feedback on } \\
\text { the extent of } \\
\text { achievement of } \\
\text { expected level of } \\
\text { performance during } \\
\text { specified period }\end{array}$ & $\begin{array}{c}\text { It determines } \\
\text { effectiveness of } \\
\text { budgeting process at the } \\
\text { organization. }\end{array}$ \\
\hline & Frequency & Percentage & Frequency & Percentage & Frequency & Percentage & Frequency & Percentage \\
\hline 1 & 0 & 0 & 0 & 0 & 0 & 0 & 0 & 0 \\
\hline 2 & 0 & 0 & 0 & 0 & 0 & 0 & 0 & 0 \\
\hline 3 & 0 & 0 & 0 & 0 & 0 & 0 & 1 & 2.5 \\
\hline 4 & 15 & 37.5 & 30 & 75 & 32 & 80 & 31 & 77.5 \\
\hline 5 & 25 & 62.5 & 10 & 25 & 8 & 20 & 8 & 20 \\
\hline Total & 40 & 100 & 40 & 100 & 40 & 100 & 40 & 100 \\
\hline
\end{tabular}

Scale: Ranging from 1 = Strongly Disagree, 2 =Disagree, $3=$ Undecided, $4=$ Agree, $5=$ Strongly Agree

This table shows the response of budget control questions, $37.5 \%$ agreed and $62.5 \%$ strongly agreed that budget control reports are used as a basis for evaluating managerial performance. $75 \%$ agreed and $25 \%$ strongly agreed that budget control ensures all transactions are recorded at obligation and payment stage. While $80 \%$ agreed and $20 \%$ strongly agreed that budget control provides feedback on the extent of achievement of expected level of performance during specified period. As for if budget control determines effectiveness of budgeting process at the organization, $77.5 \%$ agreed, $20 \%$ strongly agreed and $2.5 \%$ were undecided.

Table 4 shows the results on financial performance.

Scale: Ranging from 1 = Very low extent, 2 = Low extent, $3=$ Moderate extent, $4=$ Great extent, 5 $=$ Very great extent. This table shows the response of financial performance questions, $62.5 \%$ said budgetary control affect net profit of their organization by great extent and $37.5 \%$ by very great. Also $70 \%$ said budgetary control affect Return on asset of their organizations by great extent, $5 \%$ by great extent and $25 \%$ by moderate extent. 
Table 4. Financial Performance

\begin{tabular}{|c|c|c|c|c|}
\hline Scale & $\begin{array}{c}\text { To what extent does budgetary } \\
\text { control relate to net profit of your } \\
\text { organization }\end{array}$ & $\begin{array}{c}\text { To what extent does budgetary control relate to Return on } \\
\text { asset of your organization }\end{array}$ \\
\hline & Frequency & Percentage & Frequency & Percentage \\
\hline 1 & 0 & 0 & 0 & 0 \\
\hline 2 & 0 & 0 & 0 & 25 \\
\hline 3 & 0 & 0 & 28 & 70 \\
\hline 4 & 25 & 62.5 & 2 & 5 \\
\hline 5 & 15 & 37.5 & 40 & 100 \\
\hline Total & 40 & 100 & & 0 \\
\hline
\end{tabular}

\subsection{Data Analysis}

\subsubsection{Test of Hypothesis}

\section{Test of Hypothesis 1}

$\mathrm{HO}_{1}$ : There is no significant relationship between budgetary control and net profit of governmentowned companies in Rivers State.

Table 5. Pearson's Correlation Coefficients for net profit and budgetary control

\begin{tabular}{llcc}
\hline \multirow{2}{*}{ Net Profit } & & Net Profit & Budgetary Control \\
& Pearson Correlation & 1 & $.769(*)$ \\
& Sig. (2-tailed) & & .048 \\
Budgetary Control & N & 40 & 40 \\
& Pearson Correlation & $.769\left(^{*}\right)$ & 1 \\
& Sig. (2-tailed) & .048 & 40 \\
\hline
\end{tabular}

* Correlation is significant at the 0.05 level (2-tailed).

** Correlation is significant at the 0.01 level (2-tailed).

From the correlation result in table 5 , net profit has a positive correlation of 0.769 with Budget control which is significant at 0.01 . Table 6 , revealed that the probability/significant value is $0.00<0.05$ level or significance, which reveals that budgetary control and net profit has a positive relationship. We therefore reject the null hypothesis and accept the alternate hypothesis which states that there is a significant relationship between budgetary control and net profit of government-owned companies in Rivers State. This means that net profit increases when there is good budget control. So governmentowned companies in Rivers State with a good budget control are more likely to get high net profit (perform better financially).

\section{Test of Hypothesis 2}

$\mathrm{HO}_{2}$ : There is no significant relationship between budgetary control and return on asset of government-owned companies in Rivers State.

Table 6. Pearson's Correlation Coefficients for Return on asset and budgetary control

\begin{tabular}{|c|c|c|c|}
\hline & & Return on Asset & Budgetary Control \\
\hline \multirow[t]{3}{*}{ Return on Asset } & Pearson Correlation & 1 & $.860(* *)$ \\
\hline & Sig. (2-tailed) & & .005 \\
\hline & $\mathrm{N}$ & 40 & 40 \\
\hline \multirow[t]{3}{*}{ Budgetary Control } & Pearson Correlation & $.860\left(^{* *}\right)$ & 1 \\
\hline & Sig. (2-tailed) & .005 & \\
\hline & $\mathrm{N}$ & 40 & 40 \\
\hline
\end{tabular}

\footnotetext{
* Correlation is significant at the 0.05 level (2-tailed).
}

** Correlation is significant at the 0.01 level (2-tailed). 
From the correlation result in table 6 , Return on asset has a positive correlation of 0.860 with budgetary control which is significant at 0.01 . Table 6 , revealed that the probability/significant value is $0.00<0.05$ level or significance, which reveals that budgetary control and return on asset has a high positive relationship. We therefore reject the null hypothesis and accept the alternate hypothesis which states that there is a significant relationship between budgetary control and return on asset of government-owned companies in Rivers State. This means that return on asset increases when there is an effective budgetary control. So government-owned companies in Rivers State with a good budgetary control are more likely to get high return on asset (perform better financially).

\subsection{Summary}

From the outcome of the analysis and interpretation as relate to the questions in the questionnaire for the study and also as they relate to the testing of the hypothesis, the following findings were made:

1. From the analysis in table 4, In terms of the relationship between budgetary control and net profit of government-owned companies in Rivers State, the result showed that there is a relationship between budgetary control and net profit. This means that net profit increases when there is good budget control. So government-owned companies in Rivers State with a good budget control are more likely to get high net profit (perform better financially).

2. From the analysis in table 5 , In terms of the relationship between budgetary control and return on asset of government-owned companies in Rivers State, the result showed that there is a relationship between budgetary control and return on asset. This means that return on asset increases when there is an effective budgetary control. So government-owned companies in Rivers State with a good budgetary control are more likely to get high return on asset (perform better financially).

\section{Conclusions}

The study concludes that budgetary control system can be used as a control mechanism to strengthen performance measurement systems. An organization should put in place appropriate budgetary control systems which will assist in accomplishing a principle and element of the budget process. The findings indicates that budgetary control is an important aspect of an organization's budgetary system because they promote more positive attitudes and behaviours on the part of managers, supervisors and employers with budget responsibility, which ultimately will enable the organization to better accomplish its goals and objectives.

\section{Recommendations}

The study therefore recommends that for improved performance in these companies, GOCs should continue to adopt improved budgetary control measures in totality.

\section{References}

1. Adongo, K.O. (2012).The Relationship between Budgetary Controls and Financial Performance of State cooperation in Kenya. Unpublished MBA Project: Kenyatta University.

2. Aduke, B. (2007). Public Enterprise Reform in Nigeria (pp.289). Ibadan: Macmillan Press.

3. Ashok K Mishra, C. W. (2009). Factors affecting financial performance of new and beginning Farmers. Financial Agricultural Review, $160-179$.

4. Chai, T.J (2011). The impact of capital budgeting techniques on the financial performance of courier companies in Kenya. http://erepository.uonbi.ac.ke/bitstream/handle/11295/6073/Chai_ The\%20impact\%20of\%20capital\%20budgeting\%20techniques\%20on\%20the\%20financial\%20performance\% 20of\%20courier\%20companies.pdf;sequence $=1$

5. Cropper, P. and Drury, C. (1996), Management accounting practices in universities, Management Accounting, vol. 74, ISS 2, pp. 28

6. Kiringai, J. A (2002). Budget Reforms and Medium term expenditure framework in Kenya, KIPPRA, working, Nairobi, . Nairobi: Kenya Institute for Public policy, Research and Analysis. 
7. Lewis, C.W. \& Hildreth, W.B. (2013). Budgeting: Politics and Power. (2 ${ }^{\text {nd }}$ Ed.).New York. Oxford University Press.

8. McMillan, J. H. (2001). Essential Assessment Concepts for Teachers and Administrators. Margah, M. P. (2005). Financial Management and Control in Higher Education. New York: Routledgefalme.

9. McMillan, J. H. (2001). Essential Assessment Concepts for Teachers and Administrators. Thousand Oaks, CA: Corwin Publishing Company.

10.Merika, K. S. (2008). Firms Management Competence: Does it matter. University of Peloponnese: Department of Economics.

11.Nancy N. Nafula, J. K. (2004). Budget Mechanisms and Public Expenditure Tracking in Kenya. Nairobi : Kenya Institute for Public Policy ( KIPPRA.

12.Needles, S. C. (2011). Managerial Accounting. Nason, USA: South Western Cengage Learning.

13.Perrin, R. F. (2012). Human Factors in Budgeting. Retrieved February 27th, 2012, from http://www.accountingformanagement.com/human_factors_in_budgeting.htm.

14.Powers, B. E. (2010). Financial Accounting.

15.Preetabh. (2010, August 27th). Advantages of Budgetary Control. Retrieved February $26^{\text {th }}, 2012$, from http://expertscolumn.com/content/advantages-budgetary-control.

16.Scarlet, R. (2008). Official Learning System. Oxford: CIMA Publishing.

17.Surajkumar, P. (n.d.). A Study of "Budgetary Control System as a Tool of Finance Control "Need and Importance. Retrieved December 08, 2011, from http://www.scribd.com/doc/13044904/Needandimportance-of-budgetary-control- system The World Bank. (2004). Capital Integration in the East African Community. Washington D.C: World Bank. 